\title{
Comparison of inter-varietal differences in chemical composition and nutritional properties of coconut testa flour
}

\author{
S.S.K. Marasinghe ${ }^{1}$, J.M. Nazrim Marikkar ${ }^{1 *}$, C. Yalegama ${ }^{2}$, S. Wimalasiri ${ }^{3}$, G. Seneviratne ${ }^{1}$, \\ R. Weerasooriya ${ }^{1}$ and R. Liyanage ${ }^{1}$ \\ ${ }^{I}$ National Institute of Fundamental Studies, Hantana Road, Kandy. \\ ${ }^{2}$ Coconut Research Institute, Lunuwila. \\ ${ }^{3}$ Department of Food Science and Technology, Faculty of Agriculture, University of Peradeniya, Peradeniya.
}

Submitted: 28 January 2019; Revised: 13 May 2019; Accepted: 24 May 2019

\begin{abstract}
Coconut testa is the brown colour thin outer covering of the coconut endosperm. An attempt was made to convert coconut testa into flour for bakery products. In this study, chemical composition and nutritional properties of coconut testa flour of four local cultivars, namely, San Raman, Gon Thambili, Ran Thambili and Tall $\times$ Tall were compared against those of a commercial hybrid grown in Sri Lanka. Partially defatted coconut parings of each cultivar were oven-dried and ground into coconut testa flour. Moisture, crude fat, ash and crude protein contents of coconut testa flour were determined according to AOAC methods. The carbohydrate content was calculated by the difference. Inter-varietal differences of fatty acids and micro-mineral distributions were also determined. The main constituent of coconut testa flour regardless of cultivar was carbohydrate $(42.55-59.24 \%)$ followed by protein (23.82-32.22\%) and fat (7.93-23.49\%). Commercial hybrid had the highest carbohydrate content $(59.24 \%)$ while the minimum carbohydrate content was recorded for San Raman variety $(42.55 \%)$. Highest protein content was observed in Gon Thambili (32.22\%) variety while the least was observed in commercial hybrid (23.82\%). The highest fat content was noted in San Raman variety $(23.49 \%)$. Tall $\times$ Tall variety contained the least fat content $(7.93 \%)$. Maximum ash content was observed in Ran Thambili variety (5.30 \%) while the least ash content was for Gon Thambili variety (3.70\%). Highest moisture content was prevalent in San Raman variety (4.27\%) while the least was observed in commercial hybrid (2.27\%). These results suggested that coconut testa flour is a nutritious substance, which provides value addition to the under-utilised by-product of coconut processing industry.
\end{abstract}

Keywords: Coconut, coconut testa flour, fatty acids, microminerals, proximate composition.

\section{INTRODUCTION}

Coconut (Cocos nucifera L.) is a crop grown in more than 85 countries worldwide, with a total production of 54 billion nuts per annum. The island country of Sri Lanka is the world's fifth largest producer of coconuts. Coconut is grown mainly in the traditional coconut triangle, although patches of coconut cultivation could also be seen in other parts of the country. The endemic coconut germplasm of Sri Lanka consists mainly of three varieties; typica (tall palm), nana (dwarf palm), and aurantica (king coconut palm). These varieties are generally distinguishable based on their morphological characters as well as the breeding habits (Liyanage, 1958; Fernando, 1999). Despite the major characteristic differences, there are other minor variations within each variety, which lead them to be classified further into different forms of coconut known as cultivars.

As a perennial crop, coconut is one of the most economically important crops in the tropics, serving as a source of food, drink, fuel, medicine, and construction material (Lima et al., 2015). An average mature Sri Lankan type coconut is composed of about $45 \%$ husk,

\footnotetext{
*Corresponding author (nazrim.ma@nifs.ac.lk; (iD https://orcid.org/0000-0002-0133-5852)
} 
$13 \%$ shell, $22 \%$ meat and $20 \%$ water (Marikkar et al., 2009). The most economically important part of coconut is its endocarp; the hard dark core of the fruit. Inside this part is a solid white endosperm of varied thickness, depending on the maturity of the fruit (Lima et al., 2015). In an earlier report, Nathanael (1966) pointed out that the coconut endosperm had some unique features such that the layer closest to the water cavity was least rich in oil $(\sim 56.3 \%)$ while the layer nearest to the brown testa was richest in oil $(\sim 75.4 \%)$. Later investigations into this aspect showed that the oil characteristics of the brown testa were slightly different from those of the oil characteristics of inner layers of the kernel (Marikkar \& Nasyrah, 2012).

Coconut testa is the brown coloured thin outer covering of the coconut endosperm. It is an underutilised by-product of the desiccated coconut industry; it is often used as animal feed. Previous investigations by Appaiah et al. (2014) showed that it is a rich source of bioactive compounds such as phenolics and flavanoids. It has potential to be used as a functional ingredient by the food processing industry. Although, development of flour out of coconut kernel has been the interest of researchers for preparation of snack foods (Yalegama et al., 2013), the studies on utilisation of coconut testa as a source of flour is scanty. Hence, the aim of this study was to evaluate inter-cultivar differences in proximate composition, mineral content and fatty acid distribution of coconut testa flour of four indigenous coconut cultivars, namely, Gon Thambili (GT), Ran Thambili (RT), San Raman $(\mathrm{SR})$, Tall $\times$ Tall $(\mathrm{T} \times \mathrm{T})$ and commercial hybrid coconut (COM). It is believed that this information would be vital for helping to develop coconut testa flour as a raw material for nutritional improvement of the Sri Lankan society.

\section{METHODOLOGY}

Coconuts of twelve-month maturity were collected from five different local cultivars (i.e. GT, RT, SR, T×T, and COM) maintained at the varietal blocks of the Coconut Research Institute, Lunuwila, Sri Lanka during the period August 2018 to October 2018. Fifty nuts of each cultivar were sampled for seasoning followed by de-husking. Shells of the nuts were removed manually using hammers while de-pairing was done using manually operated knives. The fresh testa of individual cultivars were disintegrated separately to medium size particles using a disintegrator (Unitex Engineers, Sri Lanka). The disintegrated parings were then dried at $70{ }^{\circ} \mathrm{C}$ using a cabinet-type dehydrator (Wessberg, Martin, Germany) for 8 hrs. Two kilogram samples of dried coconut testa of each cultivar were subjected to cold press oil extraction using a micro oil expeller (Komet DD85 machine, Germany). Partially de-fatted coconut testa (less than 15\% oil content) were ground into fine coconut testa flour using a grinder. The entire process was carried out according to the sequence illustrated in Figure 1. The grounded flour samples were then stored at refrigerated $\left(4{ }^{\circ} \mathrm{C}\right)$ condition for further analysis. All chemicals used in this study were of analytical grade unless otherwise specified.

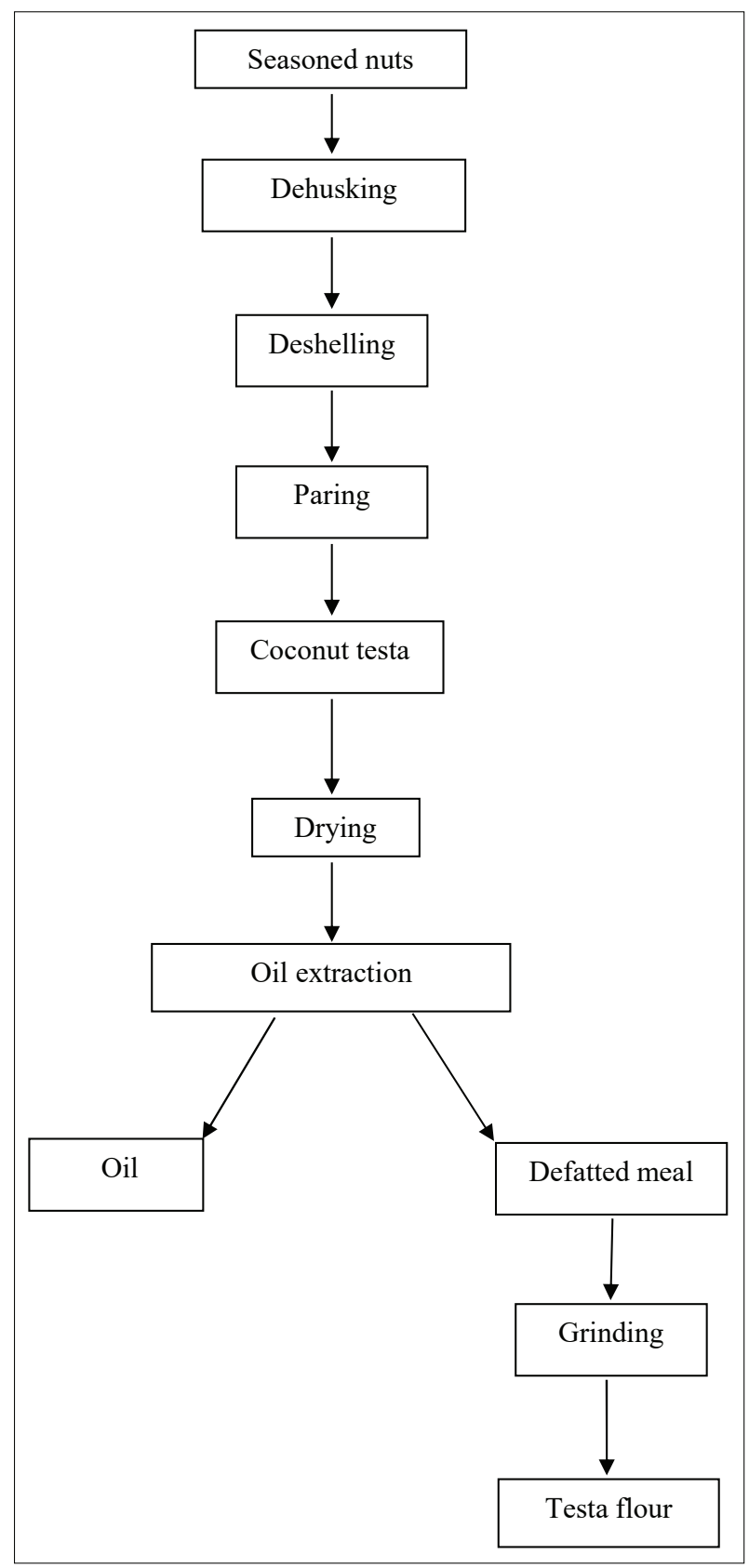

Figure 1: Process flow diagram for production of coconut testa flour 


\section{Analysis of proximate composition}

Moisture, crude fat, crude protein and ash content of coconut testa flour were determined according to methods described in AOAC (2005) manual. The carbohydrate content of the flour was calculated by the difference [100- (crude protein + crude fat + ash + moisture + crude fibre)].

\section{Analysis of micro-minerals}

Digestion of flour samples was carried out in a microwave digester (CEM MARS 6, USA) with the addition of $3 \mathrm{~mL}$ of $65 \%$ nitric acid to $0.25 \mathrm{~g}$ of flour. The digest was filtered into a $100 \mathrm{~mL}$ volumetric flask and made up to mark with distilled water. This solution was used for analysis of micro-minerals using ICP spectrophotometer (Thermo scientific, iCAP 7000 series, USA).

\section{Analysis of fatty acid profile}

A sample portion of oil ( $0.4 \mathrm{~g})$ was weighed into a screw capped glass tube and $4.0 \mathrm{~mL}$ portion of methanol and 0.1 $\mathrm{mL}$ portion of methanolic $\mathrm{KOH}$ were added. The mixture was heated to $60{ }^{\circ} \mathrm{C}$ in a water bath for $10 \mathrm{~min}$ and allowed to cool. Into this, $2 \mathrm{~mL}$ portion of hexane and 4 $\mathrm{mL}$ portion of distilled water were added. Contents were agitated at $2500 \mathrm{rpm}$ for $10 \mathrm{~min}$ in a vortex. After allowing the contents to separate into layers, the upper layer was injected into a gas chromatograph (GC-2010 Shimadzu Corporation, Japan) fitted with a flame ionisation detector (FID). The temperature of the oven was programmed as follows: the initial temperature was $130{ }^{\circ} \mathrm{C}(1 \mathrm{~min}$ hold), then increased to $170{ }^{\circ} \mathrm{C}\left(6.5^{\circ} \mathrm{C} \min ^{-1}\right), 170{ }^{\circ} \mathrm{C}$ to $215^{\circ} \mathrm{C}\left(2.75{ }^{\circ} \mathrm{C} \mathrm{min}{ }^{-1}\right)$ and maintained at $215^{\circ} \mathrm{C}$ for $12 \mathrm{~min}$. Thereafter, the temperature was increased from $215^{\circ} \mathrm{C}$ to $230{ }^{\circ} \mathrm{C}\left(4^{\circ} \mathrm{C} \mathrm{min}^{-1}\right)$ and maintained at $230{ }^{\circ} \mathrm{C}$ for $3 \mathrm{~min}$. Temperatures of the injector and detector were maintained at $270{ }^{\circ} \mathrm{C}$ and $280{ }^{\circ} \mathrm{C}$, respectively. Hydrogen was used as the carrier gas at a flow rate of $43 \mathrm{~cm} / \mathrm{sec}$. Split ratio of the injector was 50:1. Retention time of each peak was compared with that of standard fatty acid methyl esters to identify individual fatty acids. The percentage of each fatty acid was calculated by dividing the peak area of the individual fatty acid by the total of the peak areas gained for all fatty acids.

\section{Statistical analysis}

All the results from analyses were expressed as the mean value \pm standard deviation. Data were statistically analysed by one-way analysis of variance (ANOVA) using Tukey's test of MINITAB (version 14) statistical package at 0.05 probability level.

\section{RESULTS AND DISCUSSION}

\section{Moisture}

Moisture is the most abundant component of most plant foods and is also a crucial factor to determine the shelflife stability of processed products (Coultate, 2009). According to the data presented in Table 1, the mean moisture content of the testa flour of coconut cultivars was found to range from 1.8 to $4.6 \%$. The moisture content of SR was significantly higher than those of GT, T $\times$ T and RT. There was no significant difference among the mean moisture contents of $\mathrm{GT}, \mathrm{T} \times \mathrm{T}$ and RT. However, the mean moisture content of COM was significantly lower than those of GT, T $\times$ T and RT $(\mathrm{p}<0.003)$. When compared with previous reports, the moisture contents of coconut testa flour used in this study were lower than those of commercial wheat flour (Nasir et al., 2003). Organisms naturally present in the flour start to grow at high moistures, producing off odours and flavours. Hence, Nasir et al. (2003) suggested that wheat flour having less than 10\% moisture would be appropriate for extended shelf life. Further, more mold growth and insect infestation has been noticed in wheat flour having higher moisture during storage.

\section{Protein}

Proteins are the third most abundant class of macromolecules in food systems; they perform numerous biological functions in living systems (Chang, 1998). According to the data presented in Table 1, the mean protein content of the testa flour of coconut cultivars was found to range from 23.8 to $32.2 \%$. The lowest protein content was found with COM while the highest was recorded for GT. However, there was no significant difference between the protein contents of RT and SR cultivars. The mean protein content of $\mathrm{T} \times \mathrm{T}$ was significantly higher than those of RT, SR and COM. Previous researchers have examined the protein content of defatted coconut flour obtained from the whole endosperm, but not the protein content of the testa. In an early report, Ediriweera and Kashizumi (1991) pointed out that the whole endosperm of fresh coconut has about $4 \%$ protein and the value might increase in defatted meals after extraction of milk. In a study on mixed coconut types, Yalegama and Chavan (2006) found that coconut flour obtained after oil extraction of the whole kernel has around 18 to $20 \%$ of protein. According to another report, Beansch et al. (2004) reported that defatted coconut flour obtained after the extraction of virgin coconut oil contained about $20 \%$ protein; the value was higher than those reported for 
commercially milled wheat flour, which contained about $10.33 \%$ protein. The protein content is an important parameter for bread making as flour containing higher protein contents would be more expensive than flours of lower protein content. Another important feature of coconut testa flour is that its protein is gluten-free, which is advantageous for people with celiac disease or gluten intolerance.

Table 1: Inter-varietal differences in proximate composition of coconut testa flour of different coconut cultivars

\begin{tabular}{lccccc}
\hline Parameter & \multicolumn{3}{c}{ Cultivar } & & \\
& SR & GT & T $\times \mathrm{T}$ & COM \\
\hline Moisture (\%) & $4.27 \pm 0.31^{\mathrm{c}}$ & $3.40 \pm 0.53^{\mathrm{b}}$ & $3.07 \pm 0.11^{\mathrm{b}}$ & $2.80 \pm 0.40 \mathrm{~b}$ & $2.27 \pm 0.42 \mathrm{a}$ \\
Ash (\%) & $5.00 \pm 0.57^{\mathrm{c}, \mathrm{d}}$ & $3.70 \pm 0.14^{\mathrm{a}}$ & $5.30 \pm 0.14^{\mathrm{d}}$ & $4.20 \pm 0.00 \mathrm{~b}$ & $4.50 \pm 0.14 \mathrm{c}$ \\
Crude protein (\%) & $24.69 \pm 0.74^{\mathrm{a}}$ & $32.22 \pm 2.48^{\mathrm{c}}$ & $25.39 \pm 0.25 \mathrm{a}$ & $28.37 \pm 0.00 \mathrm{~b}$ & $23.82 \pm 0.99 \mathrm{a}$ \\
Crude fat (\%) & $23.49 \pm 4.91^{\mathrm{d}}$ & $13.41 \pm 4.56 \mathrm{c}$ & $13.28 \pm 0.06 \mathrm{c}$ & $7.93 \pm 2.22 \mathrm{a}$ & $10.17 \pm 1.84 \mathrm{~b}$ \\
Total carbohydrates & 42.55 & 47.27 & 52.96 & 56.7 & 59.24 \\
(by difference) (\%) & & & & & \\
\hline
\end{tabular}

Each value in the table represents the mean of three replicates. Means within each row bearing different superscripts are significantly $(\mathrm{p}<0.05)$ different.

SR - San Raman; GT - Gon Thambili; RT - Ran Thambili; T×T - Tall×Tall; COM - commercial hybrid

\section{Fat}

Dietary fat or lipid is one of the most important macronutrients that provides energy and essential fatty acids to various functions of the human body (Raihana et al., 2015). Fat contents of food usually vary from very low to high depending on the source of origin, variety, geographical location, etc. (De Man, 1999). The data presented in Table 1 compared the inter-varietal differences of fat content among the locally available coconut cultivars. The mean fat content of the testa flour of coconut cultivars was found to vary from 7.93 to $23.49 \%$. According to literature, previous researchers have examined the fat content of coconut flour obtained from the whole endosperm, but not the fat content of the testa, to compare the inter-varietal differences of local cultivars. For instance, Yalegama and Chavan (2006) reported that coconut flour obtained after oil extraction of the whole kernel had about 10 to $13 \%$ fat. In a separate communication, Beansch et al. (2004) stated that defatted coconut flour obtained after the extraction of virgin coconut oil contained about $12.0 \%$ fat (w/w, dry basis). According to Najwa et al. (2017), the fat content of defatted coconut residue left after extraction of coconut milk was found to be $17.26 \%$. All these indicated that the method of preparation or the nature of sampling in different studies could have contributed to the observed variation in fat content of different coconut testa flour samples.

\section{Fatty acid distribution}

The fatty acid distributions of oils extracted from testa flour of different cultivars were compared as shown in Table 2. The oil samples consisted of 88.75-91.23\% saturated fatty acids (SFA) and 8.76-11.19\% unsaturated fatty acid (USFA). Among the different cultivars, lauric acid was the dominant fatty acid (42.65-45.97\%), followed by myristic acid (19.69-21.46\%) and palmitic acid $(9.42-10.24 \%)$. In a previous study reporting the composition of coconut testa oil, lauric acid (42.28\%) was found to be the predominant fatty acid, followed by myristic acid (18.99\%) and palmitic (11.57\%) acid (Zhang et al., 2015). In another study to compare the composition of coconut testa oil and ordinary coconut oil, Marikkar and Nasyrah (2012) observed the proportion of fatty acids in the order of lauric $>$ myristic $>$ palmitic acids. However, some differences were observed in the proportional distribution of fatty acids in the oils of copra testa and wet-coconut testa; they took the order of lauric > myristic > oleic acids (Appaiah et al., 2014). With reference to the report of Appaiah et al. (2014), the mean proportion of lauric acid observed in the present study $(44.92 \%)$ was slightly higher than those of copra testa $(40.9 \%)$ and wet-coconut testa $(32.4 \%)$. When compared to oils from coconut testa flour of the present study $(7.02 \%)$, copra testa $(12.2 \%)$ and wet-coconut testa $(17.85 \%)$ had considerably higher oleic acid contents. However, the mean percentage of myristic 
Table 2: Inter-varietal differences in fatty acid compositions of coconut testa flour of different coconut cultivars

\begin{tabular}{lccccc}
\hline Fatty acid & \multicolumn{3}{c}{ Cultivar } & & \\
& SR & RT & GT & T $\times$ T & COM \\
\hline C8:0 & $7.62 \pm 0.01^{\mathrm{b}}$ & $8.05 \pm 0.08^{\mathrm{c}}$ & $7.60 \pm 0.01^{\mathrm{b}}$ & $8.14 \pm 0.03^{\mathrm{c}}$ & $7.33 \pm 0.01^{\mathrm{a}}$ \\
$\mathrm{C} 10: 0$ & $4.96 \pm 0.01^{\mathrm{c}}$ & $5.32 \pm 0.03^{\mathrm{d}}$ & $4.72 \pm 0.11^{\mathrm{b}}$ & $5.21 \pm 0.04^{\mathrm{d}}$ & $4.45 \pm 0.03^{\mathrm{a}}$ \\
$\mathrm{C} 12: 0$ & $45.48 \pm 0.03^{\mathrm{b}, \mathrm{c}}$ & $45.97 \pm 0.23^{\mathrm{c}}$ & $45.23 \pm 0.1^{\mathrm{b}}$ & $45.29 \pm 0.11^{\mathrm{b}}$ & $42.65 \pm 0.21^{\mathrm{a}}$ \\
$\mathrm{C} 14: 0$ & $20.25 \pm 0^{\mathrm{b}}$ & $19.69 \pm 0.06^{\mathrm{a}}$ & $21.46 \pm 0.03^{\mathrm{c}}$ & $20.2 \pm 0.04^{\mathrm{b}}$ & $21.15 \pm 0.21^{\mathrm{c}}$ \\
$\mathrm{C} 16: 0$ & $9.84 \pm 0.03^{\mathrm{b}}$ & $9.42 \pm 0.11^{\mathrm{a}}$ & $9.55 \pm 0.06^{\mathrm{a}}$ & $9.43 \pm 0.04^{\mathrm{a}}$ & $10.24 \pm 0.04^{\mathrm{c}}$ \\
$\mathrm{C} 18: 0$ & $2.23 \pm 0.69^{\mathrm{a}}$ & $2.55 \pm 0.35^{\mathrm{a}}$ & $2.66 \pm 0.09^{\mathrm{a}}$ & $2.52 \pm 0.11^{\mathrm{a}}$ & $2.92 \pm 0.02^{\mathrm{a}}$ \\
$\mathrm{C} 18: 1$ & $7.22 \pm 0.65^{\mathrm{a}, \mathrm{b}}$ & $6.63 \pm 0.20^{\mathrm{a}}$ & $6.27 \pm 0.05^{\mathrm{a}}$ & $7.09 \pm 0.05^{\mathrm{a}, \mathrm{b}}$ & $7.91 \pm 0.01^{\mathrm{b}}$ \\
$\mathrm{C} 18: 2$ & $2.38 \pm 0^{\mathrm{b}}$ & $2.34 \pm 0.04^{\mathrm{b}}$ & $2.49 \pm 0.07^{\mathrm{b}}$ & $2.09 \pm 0.04^{\mathrm{a}}$ & $3.28 \pm 0.02^{\mathrm{c}}$ \\
SFA & $90.39 \pm 0.66^{\mathrm{b}}$ & $91.01 \pm 0.16^{\mathrm{b}}$ & $91.23 \pm 0.02^{\mathrm{b}}$ & $90.80 \pm 0.08^{\mathrm{b}}$ & $88.75 \pm 0.06^{\mathrm{a}}$ \\
USFA & $9.6 \pm 0.65^{\mathrm{a}}$ & $8.98 \pm 0.17^{\mathrm{a}}$ & $8.76 \pm 0.02^{\mathrm{a}}$ & $9.19 \pm 0.08^{\mathrm{a}}$ & $11.19 \pm 0.01^{\mathrm{b}}$ \\
\hline
\end{tabular}

Each value in the table represents the mean of three replicates. Means within each row bearing different superscripts are significantly $(\mathrm{p}<0.05)$ different.

SR - San Raman; GT - Gon Thambili; RT - Ran Thambili; T×T - Tall×Tall; COM - commercial hybrid

C:8 - caprylic; C:10 - caproic; C12:0 - lauric, C14:0 - myristic, C16:0 - palmitic, C18:0 - stearic; C18:1 - oleic; C18:2

- linoleic; SFA - saturated fatty acid; USFA - unsaturated fatty acid

acid $(20.55 \%)$ in the present study was comparatively similar to those of copra testa $(20.9 \%)$ and wet-coconut testa $(20.2 \%)$.

The inter-varietal differences of the distribution of individual fatty acids among cultivars RT, GT, SR, $\mathrm{T} \times \mathrm{T}$ and $\mathrm{COM}$ are of considerable interest in nutrition. Generally, in this study there is no particular pattern of change among the distribution of various fatty acids. Significant differences were noticed among the cultivars with regard to the distribution of fatty acids such as caprylic acid and caproic acid, although the differences were minute. The proportion of lauric acid was highest for RT while the same for COM was lowest. Likewise, the proportion of myristic acid was highest for GT while the same for RT was lowest. Among all five cultivars, the proportions of stearic acid and unsaturated fatty acids such as oleic and linoleic acids were low. As a result, coconut testa flour of these cultivars might display better shelflife stability than wheat flour. It is because coconut testa flour with less amounts of unsaturated fatty acids than wheat flour would become less prone to auto-oxidation. In a previous study, Nikolic et al. (2015) reported that the predominant fatty acid of wheat flour was linoleic acid (66.57\%), followed by palmitic acid (15.36\%) and oleic acid (13.34 \%). According to another report by Nikolic et al. (2008), the major fatty acid of wheat flour was found to be linoleic acid (57.67\%), followed by oleic acid (20.28\%) and palmitic acid (19.56\%).

\section{Ash}

Ash is the composite material of minerals present in flour. Determination of the ash and mineral content of foods is important for a number of reasons. For instance, the quality of many foods depends on the concentration and type of minerals they contain, including the taste, appearance, texture and stability. Previous studies have shown that ash content of wheat flour varies from about 1.50 to $2.00 \%$ (NDSU, 2018). It is generally accepted that the ash content of flour does not affect the baking performance in majority of the cases (Borla et al., 2004). The data presented in Table 1 shows that ash contents of the samples ranged from 3.6 to $5.4 \%$. Mean ash content of GT was significantly $(\mathrm{p}<0.012)$ lower than those of $\mathrm{SR}, \mathrm{RT}, \mathrm{T} \times \mathrm{T}$ and COM. However, no significant $(\mathrm{p}>$ 0.05 ) differences were noticed among mean ash contents of SR, RT, $\mathrm{T} \times \mathrm{T}$ and $\mathrm{COM}$. In a previous study, Yalegama et al. (2013) observed the changing pattern of ash content among coconut flour/ or residue samples obtained from different methods of processing. For instance, the ash contents of coconut residue samples obtained after milk extraction by two different machines were found to be $1.5 \%$ (Yalegama et al., 2013) and $0.54 \%$ (Najwa et al., 2017). These differences could be due to the difference in extraction efficiencies of the two milk extractor machines used by these two groups. However, higher ash content values were noticed for coconut flour obtained through virgin coconut oil extraction. This could probably 
be because more minerals are washed away during the aqueous exaction of coconut milk, while they are retained with the defatted residue coming from coconut oil extraction.

\section{Micro-mineral distribution}

Comparing micro-mineral distribution in food stuffs is generally important for the assessment of nutritional values. Although they are required in minute quantities, micro minerals are essential to catalyse enzymatic biochemical reactions of various metabolisms. The data presented in Table 3 compares the distribution of micro-minerals present in the coconut testa flour of the cultivars. Mn was the most prevalent mineral (73.71$94.1 \mathrm{mg} / \mathrm{kg})$, followed by Zn $(29.65-57.34 \mathrm{mg} / \mathrm{kg})$ and $\mathrm{Cu}(29.94-45.14 \mathrm{mg} / \mathrm{kg})$. According to previous studies, whole coconut kernel was known to possess minerals such as $\mathrm{Fe}, \mathrm{Cu}, \mathrm{Mn}$ and $\mathrm{Zn}$ (Yalegama et al., 2013). Mn is an essential micro-mineral that acts as a cofactor to many enzymes involved in bone formation and various other metabolic processes. It is said to be present in trace amounts in a variety of food items such as nuts, whole grains, and some vegetables.

In this study, Mn content of the samples ranged from 73.71 to $94.1 \mathrm{mg} / \mathrm{kg}$; there was no statistically significant difference among the mean Mn content of RT, GT and COM. However, the mean Mn content of SR was significantly $(p<0.001)$ higher than those of RT, GT and COM. Meanwhile the mean Mn content of $T \times T$ was significantly $(p<0.001)$ lower than those of RT, GT and COM. Zn was the next most abundant micro-mineral detected in coconut testa flour of the local coconut cultivars. According to scientific studies, $\mathrm{Zn}$ is the cofactor for many enzymes affecting growth and digestion; its deficiency can lead to growth retardation, sexual immaturity and impaired immune response (Coultate, 2009). Generally, protein containing foods are a good source of zinc. In this study, $\mathrm{Zn}$ contents of the samples ranged from $29.65-57.34 \mathrm{mg} / \mathrm{kg}$. There was no statistically significant $(\mathrm{p}>0.065)$ difference in the mean Zn contents among SR, RT, GT, T $\times$ T and $\mathrm{COM}$. The next important micro-mineral is $\mathrm{Cu}$, which plays an important role in several enzymatic reactions (Coultate, 2009). It is a constituent of enzymes such as tyrosinase, cytochrome oxidase, ascorbic acid oxidase, uricase, monoamine oxidase, etc. Legumes, whole grains, nuts, shellfish, and seeds are some other sources that provide $\mathrm{Cu}$ in human nutrition. Since $\mathrm{Cu}$ is a transition metal, citrus fruit juices might help $\mathrm{Cu}$ absorption through metal chelating effect. According to Table $3, \mathrm{Cu}$ contents of coconut testa flour of cultivars were found to range from $29.94-45.14 \mathrm{mg} / \mathrm{kg}$. The mean $\mathrm{Cu}$ content was highest for RT while the mean $\mathrm{Cu}$ content decreased in order of RT, SR and GT in a statistically significant $(p<0.001)$ manner. However, there was no significant difference between the mean $\mathrm{Cu}$ content of $\mathrm{T} \times \mathrm{T}$ and $\mathrm{COM}$. The data presented in Table 3 shows that $\mathrm{Fe}$ contents of the samples were in the range of $0.48-2.6 \mathrm{mg} / \mathrm{kg}$. Fe is an essential mineral for hemoglobin and myoglobin, which are part of the oxygen transport system of the human body. Iron balance is also critical for brain function; the deficiency might lead to tiredness, fatigue and anemia (Coultate, 2009). Red meats, fish, poultry, eggs, and legumes are

Table 3: Inter-varietal differences in mineral composition of coconut testa flour of different cultivars

\begin{tabular}{lccccc}
\hline Mineral element & \multicolumn{5}{c}{ Cultivar } \\
& SR & RT & GT & T×T & COM \\
\hline $\mathrm{Ni}(\mathrm{mg} / \mathrm{kg})$ & $6.54 \pm 0.67^{\mathrm{c}}$ & $6.69 \pm 1.5^{\mathrm{c}}$ & $3.17 \pm 78.4^{\mathrm{b}}$ & $2.12 \pm 0.10^{\mathrm{a}}$ & $3.89 \pm 0.04^{\mathrm{b}}$ \\
$\mathrm{Zn}(\mathrm{mg} / \mathrm{kg})$ & $46.7 \pm 6.50^{\mathrm{b}}$ & $54.5 \pm 4.00^{\mathrm{c}}$ & $44.5 \pm 8.50^{\mathrm{b}}$ & $33.4 \pm 5.30^{\mathrm{a}}$ & $36.2 \pm 0.70^{\mathrm{a}}$ \\
$\mathrm{Mn}(\mathrm{mg} / \mathrm{kg})$ & $93.82 \pm 0.38^{\mathrm{d}}$ & $89.20 \pm 0.41^{\mathrm{c}}$ & $85.62 \pm 3.02^{\mathrm{b}}$ & $75.30 \pm 2.25^{\mathrm{a}}$ & $83.60 \pm 1.43^{\mathrm{b}}$ \\
$\mathrm{Cr}(\mathrm{mg} / \mathrm{kg})$ & $6.78 \pm 0.65$ & $7.56 \pm 0.32$ & $1.97 \pm 0.02$ & $0.68 \pm 0.02$ & $0.35 \pm 0.02^{\mathrm{a}}$ \\
$\mathrm{Co}(\mathrm{mg} / \mathrm{kg})$ & $0.15 \pm 0.57$ & $0.21 \pm 0.03$ & $0.11 \pm 0.00$ & $0.07 \pm 0.01^{\mathrm{a}}$ & $0.16 \pm 0.00$ \\
$\mathrm{Cu}(\mathrm{mg} / \mathrm{kg})$ & $38.7 \pm 0.70$ & $44.7 \pm 0.70$ & $34.8 \pm 0.90$ & $30.5 \pm 0.80^{\mathrm{a}}$ & $31.0 \pm 0.70^{\mathrm{a}}$ \\
$\mathrm{Fe}(\mathrm{mg} / \mathrm{kg})$ & $2.60 \pm 0.16^{\mathrm{c}}$ & $1.38 \pm 0.41^{\mathrm{b}}$ & $0.91 \pm 0.64^{\mathrm{a}}$ & $0.48 \pm 0.26^{\mathrm{a}}$ & $0.61 \pm 0.00^{\mathrm{a}}$ \\
$\mathrm{Ba}(\mathrm{mg} / \mathrm{kg})$ & $1.1 \pm 0.02^{\mathrm{c}}$ & $1.19 \pm 0.11^{\mathrm{c}}$ & $0.52 \pm 0.09^{\mathrm{b}}$ & $0.36 \pm 0.10^{\mathrm{a}}$ & $0.51 \pm 0.03^{\mathrm{b}}$ \\
$\mathrm{Mo}(\mathrm{mg} / \mathrm{kg})$ & $0.26 \pm 0.01^{\mathrm{b}}$ & $0.31 \pm 0.08^{\mathrm{b}}$ & $0.12 \pm 0.00^{\mathrm{a}}$ & $0.12 \pm 0.01^{\mathrm{a}}$ & $0.09 \pm 0.03^{\mathrm{a}}$ \\
\hline
\end{tabular}

Each value in the table represents the mean of three replicates. Means within each row bearing different superscripts are significantly $(\mathrm{p}<0.05)$ different.

SR - San Raman; GT - Gon Thambili; RT - Ran Thambili; T×T - Tall $\times$ Tall; COM - commercial hybrid 
usually good sources of Fe. The mean Fe contents of RT $(1.38 \pm 0.41 \mathrm{mg} / \mathrm{kg}), \mathrm{GT}(0.91 \pm 0.64 \mathrm{mg} / \mathrm{kg}), \mathrm{T} \times \mathrm{T}$ $(0.48 \pm 0.26 \mathrm{mg} / \mathrm{kg})$ and COM $(0.61 \pm 0.00 \mathrm{mg} / \mathrm{kg})$ were more or less equal, but significantly lower $(\mathrm{p}<0.05)$ than that of SR $(2.60 \pm 0.16 \mathrm{mg} / \mathrm{kg})$.

\section{Total carbohydrate content}

Total carbohydrates consist of multiple nutrients, which include dietary fibre, sugars and starches. The data presented in Table 1 compares the total carbohydrate contents of coconut testa flour obtained from five local coconut cultivars. The total carbohydrate contents of the samples were found to range from 59.24-42.55\%; the mean total carbohydrate content was lowest for SR variety, while the highest value of the same was recorded for COM. The inter-varietal differences of total carbohydrates among the cultivars were significantly $(p<0.05)$ different. The carbohydrate content of coconut testa flour is generally lower than that of traditional grain flours such as wheat flour. Kassegn (2018) reported that $100 \mathrm{~g}$ of wheat flour might contain around 64-72 $\mathrm{g}$ of carbohydrates while David et al. (2015) found that the total carbohydrate content of soft wheat flour was around $83 \%$. According to previous reports of Yalegama and Chavan (2006), the total carbohydrate content of coconut flour was around $50 \%$. In a separate study, Beansch et al. (2004) also reported that the total carbohydrate content of defatted coconut flour obtained after the extraction of virgin coconut oil was about $52.0 \%$ (w/w, dry basis). The occurrence of higher proportions of fat and protein in coconut flour would be a reason for the lower proportion of total carbohydrates. In addition, the quality of carbohydrate is also dependent on its fibre content and glycemic index. As it contains enough fibrous matter, it can also be useful as a thickening agent in sauces or soups. In a previous study, Leelavathi and Rao (1993) reported that wheat flour contained a low amount of total dietary fibre and therefore, supplementation of wheat flour with defatted coconut flour could increase the dietary fibre content of food formulations.

\section{CONCLUSIONS}

In this study, inter-varietal differences of chemical composition and nutritional properties of coconut testa flour of different indigenous cultivars were compared. In general, coconut testa flour of all cultivars displayed higher contents of protein and fat than wheat flour; hence partial substitution of wheat flour with coconut testa flour would improve the nutritional quality of flour-based products. Among the different cultivars, the highest protein content was observed in GT while the lowest protein value was observed for COM variety. The highest fat content was noted in SR while least fat content was found in $\mathrm{T} \times \mathrm{T}$. The maximum ash content was found in RT while the lowest ash content was in GT variety. COM hybrid had the highest carbohydrate content while the lowest carbohydrate content was recorded for SR variety. In general, coconut testa flour of all cultivars contained micro-minerals such as $\mathrm{Mn}$, $\mathrm{Cu}$ and $\mathrm{Zn}$. There were noticeable cultivar differences with regard to mineral composition. Highest amounts of $\mathrm{Fe}$ and $\mathrm{Mn}$ were present in SR while the highest content of $\mathrm{Cu}$ and $\mathrm{Zn}$ were found with RT. All these findings suggest that coconut testa flour can become a potential source for value addition purposes and reduce the wastage of under-utilised coconut testa generated by the coconut processing sector.

\section{Acknowledgements}

Authors gratefully acknowledge provision of coconut samples and analytical services by the Coconut Research Institute of Sri Lanka.

\section{REFERENCES}

AOAC International (2005). Official Methods of Analysis of $A O A C$ International, $18^{\text {th }}$ edition. AOAC International, Rockville, Maryland, USA.

Appaiah P., Sunil L., Kumar P.K.P. \& Krishna A.G.G. (2014). Composition of coconut testa, coconut kernel and its oil. Journal of the American Oil Chemists' Society 91: 917924.

DOI: https://doi.org/10.1007/s11746-014-2447-9

Baensch W., Yalegama C. \& Jayasundera J.M.M.A. (2004). New technologies of coconut processing-part I: process for production of virgin coconut oil and low fat / high protein coconut flour from coconut kernel, pp. 261-269, Proceeding II of the International Coconut Conference-2004 (eds. T.S.G. Peiris \& C.S. Ranasinghe), Coconut Research Institute of Sri Lanka, Lunuwila.

Borla O.P., Motta E.L., Saiz A.I. \& Fritz R. (2004). Quality parameters and baking performance of commercial gluten flours. LWT-Food Science and Technology 37: 723-729. DOI: https://doi.org/10.1016/j.lwt.2004.02.013

Chang S.K.C. (1998). Food Analysis (ed. S.S. Nielson). Aspens Publisher Inc., USA.

Coultate T.P. (2009). Food: The Chemistry of its Components. The Royal Society of Chemistry, Cambridge, UK.

David O., Arthur E., Samuel O.K., Badu E. \& Patrick S. (2015). Proximate composition and some functional properties of soft wheat flour. International Journal of Innovative Research in Science, Engineering and Technology 4: 753-758. 
De Man J.M. (1999). Principles of Food Chemistry. Van Nostrand Reinhold, New York, USA.

Ediriweera N. \& Hashizumi K. (1991). Extractability of coconut protein and changes in its gel forming properties on heating. Journal of the National Science Council of Sri Lanka 19: 115-128.

DOI: https://doi.org/10.4038/jnsfsr.v19i2.8159

Fernando W.M.U. (1999). APCC-BUROTROP-COGENT. Project on the assessment of the performance of high yielding coconut varieties (HYCVs)/hybrids and the varietal preferences of coconut farmers: a country report for Sri Lanka. Asian and Pacific Coconut Community, Yogyakarta, Indonesia.

Kasseng H.H. (2018). Determination of proximate composition and bioactive compounds of the Abyssinian purple wheat. Cogent Food and Agriculture 4(1): 1421415. DOI: https://doi.org/10.1080/23311932.2017.1421415

Leelavathi K. \& Rao P.H. (1993). Development of high fiber biscuits using wheat bran. Journal of Food Science and Technology 30: 187-190.

Lima E.B.C., Sousa C.N.S., Meneses L.N., Ximenes N.C., Santos Júnior M.A., Vasconcelos G.S., Lima N.B.C., Patrocínio M.C.A., Macedo D. \& Vasconcelos S.M.M. (2015). Cocos nucifera (L.) (Arecaceae): a phytochemical and pharmacological review. Brazilian Journal of Medical and Biological Research 48: 953-964. DOI: https://doi.org/10.1590/1414-431x20154773

Liyanage D.V. (1958). Varieties and forms of the coconut palm grown in Ceylon. Ceylon Coconut Quarterly 9: 1-10.

Marikkar J.M.N., Banu M.K.I. \& Yalegama C. (2009). Evaluation of the modified-Ceylon copra kiln for accelerated production of ball copra. International Food Research Journal 16: 175-181.

Marikkar J.M.N. \& Madurapperuma W.S. (2012). Coconut. In: Tropical and Subtropical Fruits: Postharvest Physiology, Processing and Packaging (ed. Muhammed Siddiq). JohnWiley Publishing Co., Ames, Iowa, USA.

DOI: https://doi.org/10.1002/9781118324097.ch9

Marikkar J.M.N. \& Nasyrah A.R. (2012). Distinguishing coconut oil from coconut pairing oil using principle component analysis of fatty acid data. International Journal of Coconut Research and Development 28: 9-13.

Nasir M., Masood S.B., Faquir M.A., Sharief K. \& Minhas R. (2003). Effect of moisture on shelf-life of wheat flour. International Journal of Agriculture and Biology 5: 458-459.

Nathanael W.R.N. (1966). Moisture and other quality factors of copra. Ceylon Coconut Quarterly 17: 1-41.

NDSU (2018). Available at https://www.ndsu.edu/faculty/ simsek/wheat/flour.html. Accessed 4 December 2018.

Nikolic N., Radulović N., Momcilovic B., Nikolic G.S., Lazic M.L. \& Todorovic Z. (2008). Fatty acids composition and rheology properties of wheat and wheat and white or brown rice flour mixture. European Food Research and Technology 227: 1543-1548.

DOI: https://doi.org/10.1007/s00217-008-0877-z

Nikolić N., Stojanović J., Mastilović J., Lazić M., Karabegović I. \& Stojanović G. (2015). Rheology properties and acylglycerols and fatty acid composition of the wheat flour supplemented with Boletus edulis flour. Advanced Technologies 4: 79-85. DOI: https://doi.org/10.1007/s13197-016-2448-9

Nur Ain Najwa N.M., Abbasiliasi S., Marikkar J.M.N., Lamasudin D.U., Shuhaimi M., Arbakariya A., Mehnoursh A. \& Yazid A.M.M. (2017). Defatted coconut residue crude polysaccharides as potential prebiotics on proliferation and acidifying activity of probiotics in vitro. Journal of Food Science and Technology 54: 164-173. DOI: https://doi.org/10.1007/s13197-016-2448-9

Raihana A.R., Marikkar J.M.N., Ismail A. \& Musthafa S. (2015). A review on food values of selected fruits' seeds. International Journal of Food Properties 18: 2380-2392. DOI: https://doi.org/10.1080/10942912.2014.980946

Ramaswamy L. (2006). Preparation of coconut flour-its keeping quality and acceptability in recipes. Indian Coconut Journal 36: 13-16.

Ranasinghe C.S., Wimalasekara R., de Saram P.S.A. \& Fernando W.P.K.F. (2003). Preservation of young king coconuts (Cocos nucifera var. aurantiaca) during simulated sea shipment. Asean Food Journal 12: 175-181.

Ranasinghe C.S., Wimalasekara R. \& Jayasekara C. (1999). Effect of storage temperature and wrapping treatments on the keeping quality of tender king coconut. Cocos $\mathbf{1 3}$ : 16-22.

DOI: https://doi.org/10.4038/cocos.v13i0.2171

Yalegama L.L.W.C., Karunaratne D.N., Sivakanesan R. \& Jayasekara C. (2013). Chemical and functional properties of fibre concentrates obtained from by-products of coconut kernel. Food Chemistry 141: 124-130.

DOI: https://doi.org/10.1016/j.foodchem.2013.02.118

Yalegama L.L.W.C. \& Chavan J.K. (2006). Studies on utilization of coconut flour as a source of cell wall polysaccharides. Tropical Agricultural Research 18: 126-134.

Zhang Y., Zheng Y., Duan K. \& Gui Q. (2015). Preparation, antioxidant activity and protective effect of coconut testa oil extraction on oxidative damage to human serum albumin. International Journal of Food Science and Technology 51: 946-953. DOI: https://doi.org/10.1111/ijfs.12945 